\title{
Implication of scavenger receptors in the interactions between diesel exhaust particles and immature or mature dendritic cells Solenne Taront ${ }^{1}$, Audrey Dieudonné ${ }^{1}$, Simon Blanchard ${ }^{2}$, Pascale Jeannin ${ }^{2,3}$, Philippe Lassalle ${ }^{1}$, Yves Delneste ${ }^{2,3}$ and Philippe Gosset*1
}

Address: ${ }^{1}$ INSERM, U774, Lille, F-59019, France; Institut Pasteur de Lille, Lille, F-59019, France; Univ Lille II, Lille, F-59000 France, 2 INSERM U892, Centre de Recherche sur le Cancer Nantes Angers, Angers F-49933, France; University of Angers, Angers, France and ${ }^{3}$ Immunology and Allergology department, University Hospital of Angers, Angers, 49933, France

Email: Solenne Taront - solenne_taront1980@yahoo.fr; Audrey Dieudonné - aud_dieudonne@yahoo.fr; Simon Blanchard - simon.blanchard@univ-angers.fr; Pascale Jeannin - pascale.jeannin@univ-angers.fr; Philippe Lassalle - Philippe.Lassalle@pasteur-lille.fr; Yves Delneste - yves.delneste@univ-angers.fr; Philippe Gosset* - Philippe.Gosset@pasteurlille.fr

* Corresponding author

Published: 13 March 2009

Particle and Fibre Toxicology 2009, 6:9 doi:10.1186/1743-8977-6-9

Received: 14 August 2008

Accepted: 13 March 2009

This article is available from: http://www.particleandfibretoxicology.com/content/6/1/9

(C) 2009 Taront et al; licensee BioMed Central Ltd.

This is an Open Access article distributed under the terms of the Creative Commons Attribution License (http://creativecommons.org/licenses/by/2.0), which permits unrestricted use, distribution, and reproduction in any medium, provided the original work is properly cited.

\begin{abstract}
Background: The exposure to pollutants such as diesel exhaust particles (DEP) is associated with an increased incidence of respiratory diseases. However, the mechanisms by which DEP have an effect on human health are not completely understood. In addition to their action on macrophages and airway epithelial cells, DEP also modulate the functions of dendritic cells (DC). These professional antigenpresenting cells are able to discriminate unmodified self from non-self thanks to pattern recognition receptors such as the Toll like Receptors (TLR) and Scavenger Receptors (SR). SR were originally identified by their ability to bind and internalize modified lipoproteins and microorganisms but also particles and TLR agonists. In this study, we assessed the implication of SR in the effects of DEP associated or not with TLR agonists on monocyte-derived DC (MDDC). For this, we studied the regulation of CD36, CXCLI6, LOX-I, SR-AI and SR-BI expression on MDDC treated with DEP associated or not with TLR2, 3 and 4 ligands. Then, the capacity of SR ligands (dextran sulfate and maleylated-ovalbumin) to block the effects of DEP on the function of lipopolysaccharide (LPS)-activated DC has been evaluated.
\end{abstract}

Results: Our data demonstrate that TLR2 agonists mainly augmented CXCLI6, LOX-I and SR-BI expression whereas DEP alone had only a weak effect. Interestingly, DEP modulated the action of TLR2 and TLR4 ligands on the expression of LOX-I and SR-BI. Pretreatment with the SR ligand maleylatedovalbumin but not dextran sulfate inhibited the endocytosis of DEP by MDDC. Moreover, this SR ligand blocked the effect by DEP at low dose $(1 \mu \mathrm{g} / \mathrm{ml})$ on MDDC phenotype (a decrease of CD86 and HLA-DR expression) and on the secretion of CXCLI0, IL-I2 and TNF- $\alpha$. In contrast, the decrease of IL-I2 and CXCLI0 secretion and the generation of oxygen metabolite induced by DEP at $10 \mu \mathrm{g} / \mathrm{ml}$ was not affected by SR ligands

Conclusion: Our results show for the first time that the modulation of DC functions by DEP implicates SR. TLR agonists upregulated SR expression in contrast to DEP. Interfering with the expression and/or the function of SR might be one way to limit the impact of DEP on lung immune response. 


\section{Background}

Airway mucosa represents the first line of defence against invading airborne pathogens and particulate matters. A high level of airborne particulate matters within the inspired air is associated with an increased incidence of respiratory diseases like allergic asthma and rhinitis [1]. Among these pollutants, road traffic and particularly the diesel cars represent a major source of particulate matters in urban area. Exposure to diesel exhaust particles (DEP) is associated with exacerbations of asthma, chronic obstructive pulmonary disease and allergic rhinitis [2-4].

DEP exert immunoregulatory functions through their first action on resident cells in the lung including macrophages, airway epithelial cells, and dendritic cells (DC). DC has been shown as playing a key role in the control of the lung immune response. These effects induced by DEP are probably responsible for its adjuvant activity that promotes pro-allergic sensitization to common environmental allergens [5], exacerbation of existing airway diseases $[6,7]$, and increased susceptibility to respiratory virus infections like influenza [8] or RSV infections [9]. Regarding the modulation of DC functions, DEP do not induce their maturation but rather slightly modulate the response to potent maturation agents such as lipopolysaccharide (LPS), a ligand of Toll-Like Receptor (TLR)4 [10,11]. This effect involves the generation of reactive oxygen species (ROS) and the inhibition of NF- $\mathrm{KB}$ activation [12]. However, the early mechanisms by which DEP affect DC functions are not completely understood.

Whereas alveolar macrophages mainly reside in the alveolar region of the lung, immature myeloid DC (mDC) constitute a dense network in close proximity to airway epithelial cells [13]. Due to their role in the lung immune response, $\mathrm{mDC}$ are also determinant in the induction and the control of allergic asthma [14]. DC are professional antigen-presenting cells that are essential for initiating adaptive immune responses. They develop from bone marrow-derived $\mathrm{CD}_{34}{ }^{+}$precursor cells that travel in the bloodstream to secondary lymphoid tissues and mainly to the airway and gut mucosa. At a steady state and after exposure to danger signals, airway epithelial cells recruit immature DC or their precursors to sample inhaled antigens $[15,16]$. After antigen processing, maturing DC leave their resident sites towards the thoracic lymph nodes, where they efficiently prime naive T cells [17]. The T cell polarizing signals delivered by DC which are defined by the degree of cell maturation, determine the issue of the T cell response and the potential development of effector or suppressor T cells.

DC are able to discriminate unmodified self from non-self and altered/modified self thanks to a large family of receptors so called the pattern recognition receptors that include signalling receptors (e.g. Toll like Receptors (TLR)) and endocytic receptors including Scavenger Receptors (SR) $[18,19]$. The type of receptor involved in Ag capture will determine its processing and the issue of Ag presentation. Signalling and endocytic receptors cooperate to finely tune the degree of DC maturation and, by this way, to impact on $\mathrm{T}$ cell activation and polarization.

SR were originally identified by their ability to bind and internalize modified lipoproteins [18]. SR not only bind modified self such as oxidized LDL but also non self (microbes). In addition to their role in atherosclerosis, SR play critical roles in tissue homeostasis and innate immunity, e.g. by inducing apoptotic cell clearance. Different cell types express SR, such as endothelial cells, macrophages and DC. In comparison with macrophages, DC express a specific profile of SR belonging to different classes including SR-A1, MARCO (class A), SR-B1/CLA-1 and CD36 (class B), LOX-1 and CXCL-16 (also named SRPSOX) (class D and E, respectively) [20]. The SR LOX-1, also known as OLR1 (oxidized low density lipoprotein (lectin-like) receptor 1 ) has also a C-type lectin-like domain (CTLD) of the type found in natural killer cell receptors (NKRs). CXCL16 also possesses a functional CXC chemokine domain active on $\mathrm{T}$ cells in addition to the mucin-like domain involved in the SR function. Although binding of DEP to alveolar macrophages was not inhibited by polyanionic ligand of SR [21], some SR such as MARCO are implicated in inert particle clearance [22].

These data suggest the implication of SR in the modulation of DC functions by DEP. Our aim is to demonstrate the involvement of SR in this process and the relationship with the activation by TLR ligands. Indeed TLR4 agonist is frequently associated with airborne particles [23]. In this work we first studied the effect of DEP on the SR expression in immature and mature DC, and second, the modulation by SR ligands of DEP uptake and effect. This role was evaluated in the context of an exposure to DEP alone or in association with TLR4 ligand. Our data demonstrate that DEP modulate the expression of some SR in immature and mature DC. Pretreatment with SR ligands allows to block some effects of DEP on cytokine production and costimulatory molecule expression by DC, at least in part through the modulation of DEP uptake. Taken together, our results show for the first time that the modulation of DC functions by DEP implicates the mobilization of SR.

\section{Results \\ Modulation of mRNA expression of the SR CD36, CXCLI 6, LOX-I, SR-AI and SR-BI/CLA-I by DEP and TLR ligands}

We first determined whether DEP alone or in costimulation with TLR2 (Pam3CSK4 $(10 \mu \mathrm{g} / \mathrm{ml})),-3$ (Polyinosinic-polycytidylic acid (poly(I:C)) $\quad(10 \mu \mathrm{g} / \mathrm{ml}), \quad-4$ 
(Lipopolysaccharide (LPS)) $(1 \mu \mathrm{g} / \mathrm{ml})$ ligands, modify the SR CD36, CXCL16, LOX-1, SR-A1 and SR-B1 mRNA expression in monocyte-derived DC (MDDC) using quantitative RT-PCR. Preliminary experiments showed that the optimal time of mRNA expression were 1 and $3 \mathrm{~h}$ stimulation (data not shown). DEP did not markedly increase the mRNA level of SR although a weak effect on CD36 was observed after $1 \mathrm{~h}$ stimulation ( $\mathrm{p}<0.05)$ (Fig 1A). The TLR2 ligand significantly increased the mRNA level of CXCL16 ( $p<0.001)$ and SR-B1 ( $p<0.001)$, after 1 h stimulation, and LOX-1 after 1 and $3 \mathrm{~h}$ stimulation (Fig 1A and $1 \mathrm{~B})(\mathrm{p}<0.05)$. TLR3 agonist slightly enhanced the mRNA level of CD36 ( $\mathrm{p}<0.05)$ after $1 \mathrm{~h}$ stimulation. TLR4 ligand significantly increased the mRNA expression of CD36 after $1 \mathrm{~h}$ stimulation ( $\mathrm{p}<0.001)$, and LOX-1 after $3 \mathrm{~h}$ stimulation. Expression of SR-A1 mRNA was not modulated by TLR agonists after 1 and $3 \mathrm{~h}$ stimulation in DC (data not shown). However, at $8 \mathrm{~h}$ activation, the TLR2 and TLR4 agonists significantly decreased its expression ( $p<0.05$, Fig 2 A) whereas the poly(IC) had no activity.

Activation by DEP combined with TLR ligands resulted in the inhibition of TLR2 ligand-induced SR-B1 expression $(\mathrm{p}<0.05)$, and TLR4 ligand-induced CD36 expression ( $\mathrm{p}$
$<0.05)$ after $1 \mathrm{~h}$ stimulation. In contrast, DEP enhanced at $3 \mathrm{~h}$ the effect of TLR2 ( $\mathrm{p}<0.05)$ and TLR4 ligands on LOX-1. Exposure to DEP did not affect the expression of SR-A1 even in the presence of TLR agonists (data not shown).

Taken together, the results showed that DEP alone had a weak effect on SR expression in comparison with that of the TLR ligands. However, DEP modulated some of the stimulatory properties of TLR agonists.

Modulation of protein expression for the CD36, CXCL I6, LOX-I, SR-AI and SR-BI/CLA-I by DEP and TLR ligands

We next determined by flow cytometry the effect of these stimuli on SR membrane expression in MDDC activated during 6 and $24 \mathrm{~h}$. At the opposite of the mRNA expression, DEP alone significantly decreased after $6 \mathrm{~h}$ stimulation the expression of CD36 $(\mathrm{p}<0.05)$ and SR-B1 $(\mathrm{p}=$ NS) whereas it did not affect the level of CXCL16 and LOX-1 (Fig 3A and 3C). TLR2 ligand significantly increased the expression of LOX-1 after 6 h stimulation ( $\mathrm{p}$ $<0.05$ ) and CXCL16 and SR-B1 after $24 \mathrm{~h}$ stimulation ( $\mathrm{p}$ $<0.05)$ whereas it significantly decreased the expression of CD36 after 24 h stimulation $(\mathrm{p}<0.05)$ (Fig 3A-D). The activation by TLR3 agonist only tended to increase
A
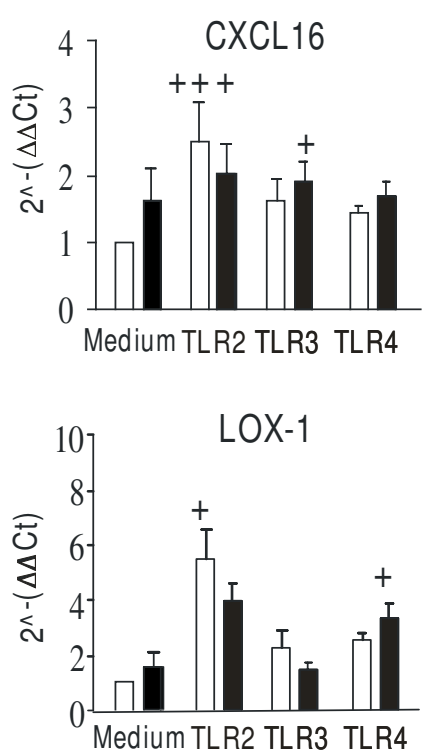
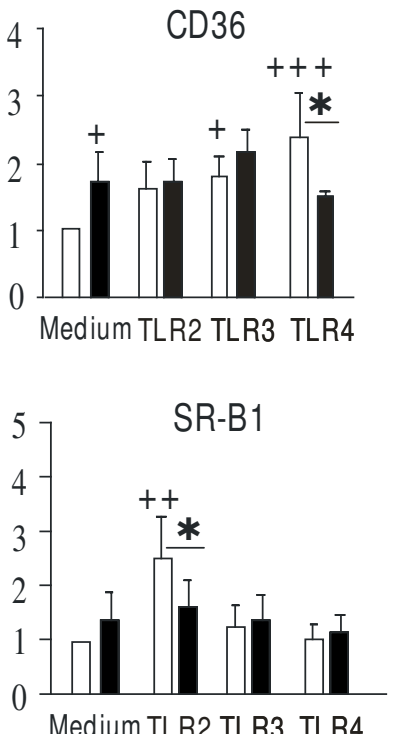

B
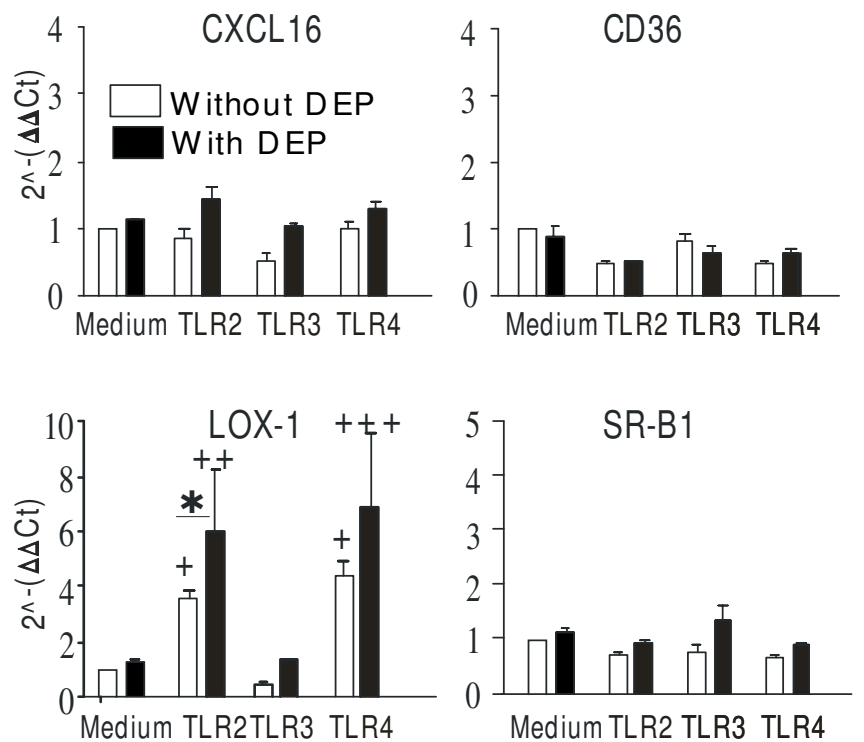

Figure I

DEP and PAMP modulate mRNA expression of Scavenger Receptors in MDDC. MDDC were maintained in medium alone or activated with TLR2, -3 and -4 ligands $\left(\mathrm{Pam}_{3} \mathrm{CSK}_{4}(10 \mu \mathrm{g} / \mathrm{ml})\right.$, poly $(\mathrm{l}: \mathrm{C})(10 \mu \mathrm{g} / \mathrm{ml})$ and LPS $(\mathrm{I} \mu \mathrm{g} / \mathrm{ml}) \mathrm{respec}-$ tively), associated or not with DEP $(10 \mu \mathrm{g} / \mathrm{ml})$ during I $\mathrm{h}$ (part $\mathrm{A})$ and $3 \mathrm{~h}$ (part B). MDDC were harvested for mRNA isolation followed by measurement of CD36, CXCLI6, LOX-I and SR-BI levels by quantitative RT-PCR. Results were expressed as the relative gene expression calculated for each experiment in folds $(2-(\Delta \Delta \mathrm{Ct}))$ compared to unstimulated cells used as calibrator. Data reported the mean \pm SEM from 4 independent experiments. $+: p<0.05 ;++: p<0.01 ;+++: p<0.001$ compared with cells in medium alone. 垸: $\mathrm{p}<0,05$ compared with TLR-treated cells. 


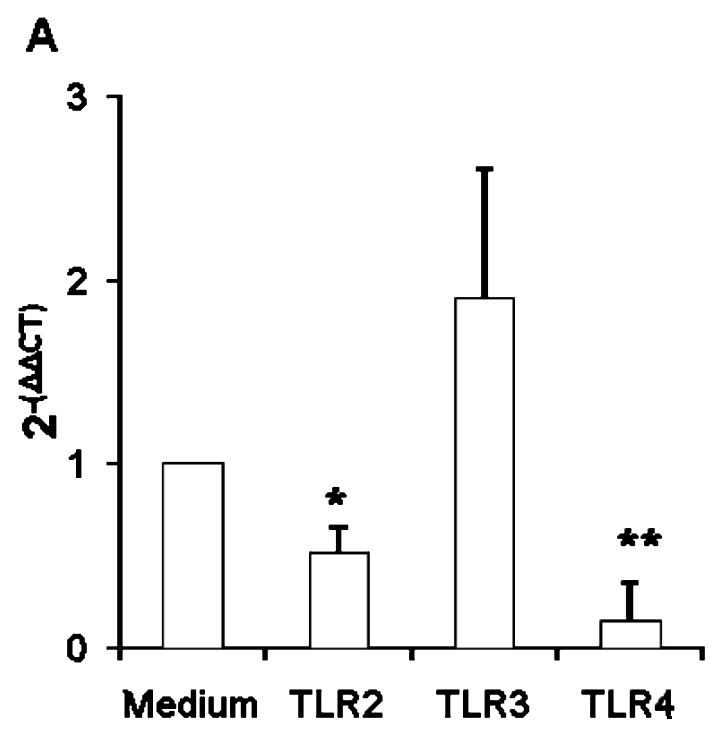

B

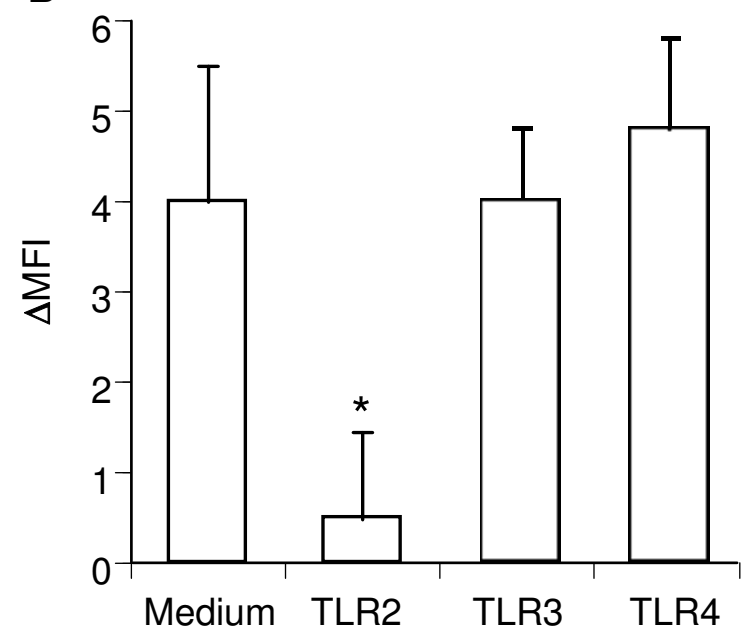

Figure 2

TLR2 activation modulates protein expression of SRAl in MDDC. MDDC were cultivated with TLR2, -3 and -4 ligands respectively $\mathrm{Pam}_{3} \mathrm{CSK}_{4}(10 \mu \mathrm{g} / \mathrm{ml})$, poly(l:C) $(10 \mu \mathrm{g} /$ $\mathrm{ml})$ and LPS $(\mathrm{l} \mu \mathrm{g} / \mathrm{ml})$ during $8 \mathrm{~h}$ for the mRNA expression (part A) and $24 \mathrm{~h}$ for the protein membrane expression (part B). A- MDDC were harvested for mRNA isolation followed by measurement of SR-AI mRNA levels by quantitative RT$P C R$. Results were expressed as the mean \pm SEM of the relative gene expression calculated for each experiment in folds $(2-(\Delta \Delta C t))$ compared to unstimulated cells used as calibrator ( $n$ $=5$ ). B- Dendritic cells were labeled for SR-AI, and analyzed by flow cytometry. Data are expressed as the mean \pm SEM from 5 independent experiments. *: $p<0.05$; **: $p<0.01$ compared with cells in medium alone.
CXCL16 expression after $24 \mathrm{~h}$. The TLR4 ligand increased LOX-1 after $24 \mathrm{~h}$ stimulation, whereas it significantly decreased the expression of CD36 after $24 \mathrm{~h}$ stimulation $(p<0.05)$. The effect of TLR2 agonist was illustrated in figure $3 \mathrm{C}-\mathrm{D}$ by histograms of flow cytometry from a representative experiment. In contrast with the effect of LPS and poly(IC), the TLR2 agonist significantly decreased the expression of SR-A1 after $24 \mathrm{~h}$ activation (Fig 2B) but not after $6 \mathrm{~h}$ (data not shown).

Associated with TLR ligands, DEP decreased the effect of the TLR2 ligand on SR-B1 expression after $24 \mathrm{~h}$ stimulation (Fig 3B and 3D), but increased the action of the TLR4 ligand after $6 \mathrm{~h}$ stimulation ( $\mathrm{p}<0.05$ ) (Fig 3B). Moreover, DEP significantly enhanced the action of TLR2 ligand on LOX-1 expression at $6 \mathrm{~h}$ stimulation $(\mathrm{p}<0.05)$.

Since SR had a rapid turnover, we have evaluated the total expression of SR in DC after 6 and $24 \mathrm{~h}$ incubation by immunofluorescence on permeabilized cells. Whereas no modulation was detected at $6 \mathrm{~h}$, activation for $24 \mathrm{~h}$ by TLR2 and TLR4 ligands significantly inhibited (33\% and $39 \%$ decrease, respectively) the intracellular labeling of anti-CD36 antibody as reported for TLR2 in the fig 4. DEP partially reversed the effect of TLR2 agonist whereas the particles alone did not modulate CD36 expression. No modulation was observed for SR-B1 and LOX-1. Concerning CXCL16, activation by TLR2 agonist increased the intracellular expression of this SR as detected on the membrane $(22 \%$ increase, $\mathrm{p}<0.05)$. In contrast, addition of DEP did not affect its expression.

Taken together, the results showed that, as reported for mRNA expression, activation by TLR ligands modulate SR membrane expression in different ways. DEP alone tend to decrease the expression of CD36 and SR-B1. Moreover, DEP modulated the effect of TLR2 and TLR4 ligands on the level of LOX-1 and SR-B1.

\section{Modulation by DEP of LPS-induced MDDC maturation: effect of SR ligands}

Since DEP modulated the expression of HLA-DR, CD83 and CD86 in LPS-stimulated MDDC [10], we studied the capacity of poly-specific SR ligands (maleylated ovalbumin and dextran sulfate) to reverse the action of DEP on MDDC maturation.

As previously described, the effect of DEP was different according to the protocol (preincubation with DEP versus co-incubation with DEP and LPS) (Fig 5). DEP at the dose of $1 \mu \mathrm{g} / \mathrm{ml}$ significantly inhibited the LPS-induced upregulation of CD86 and HLA-DR ( $<<0.05)$ when the ligands were added simultaneously. Addition of dextran sulfate and maleylated-ovalbumin blocked the inhibitory effect of DEP on LPS-stimulated DC $(p<0.05)$. In contrast, 

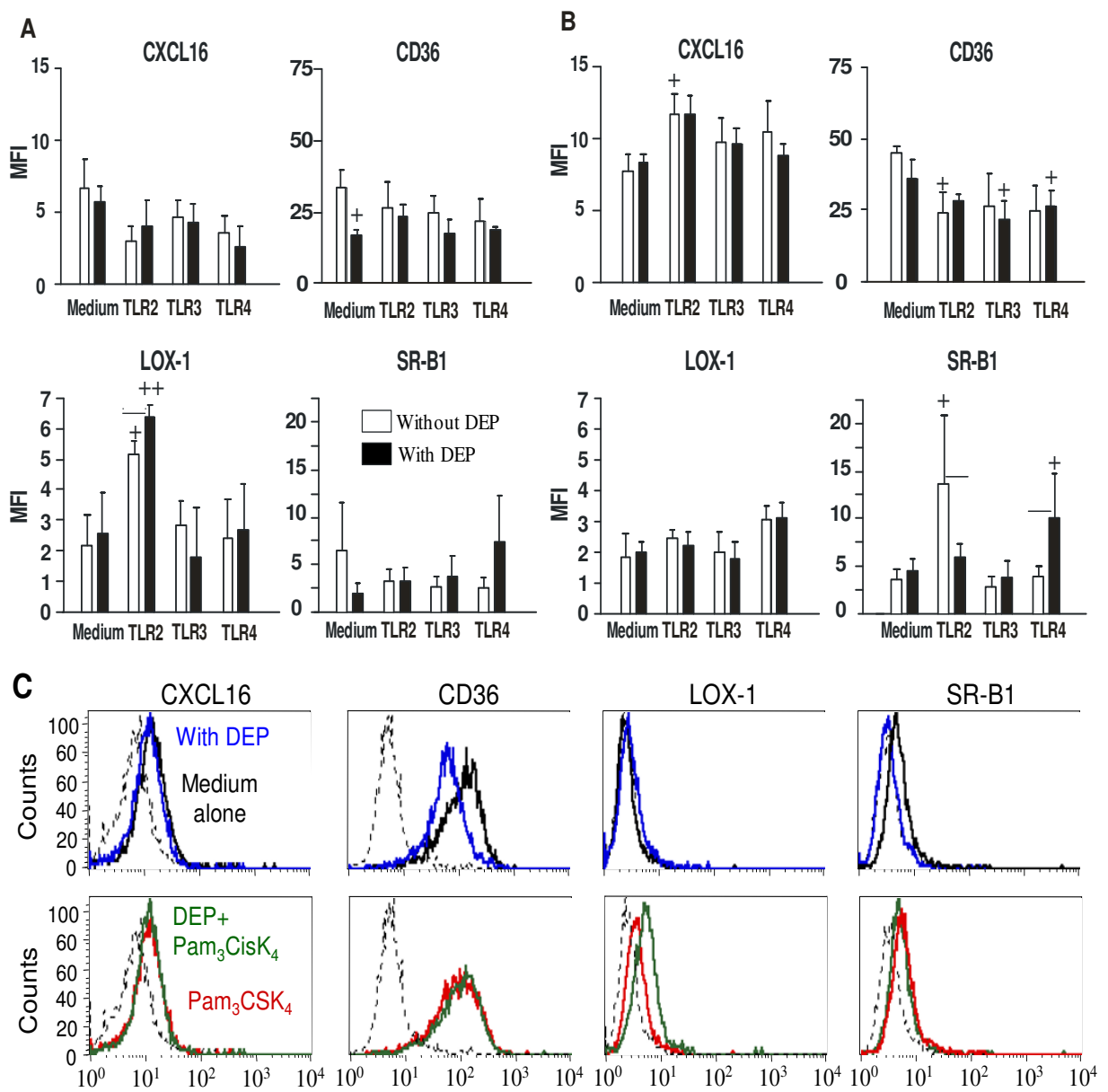

D

CXCL16
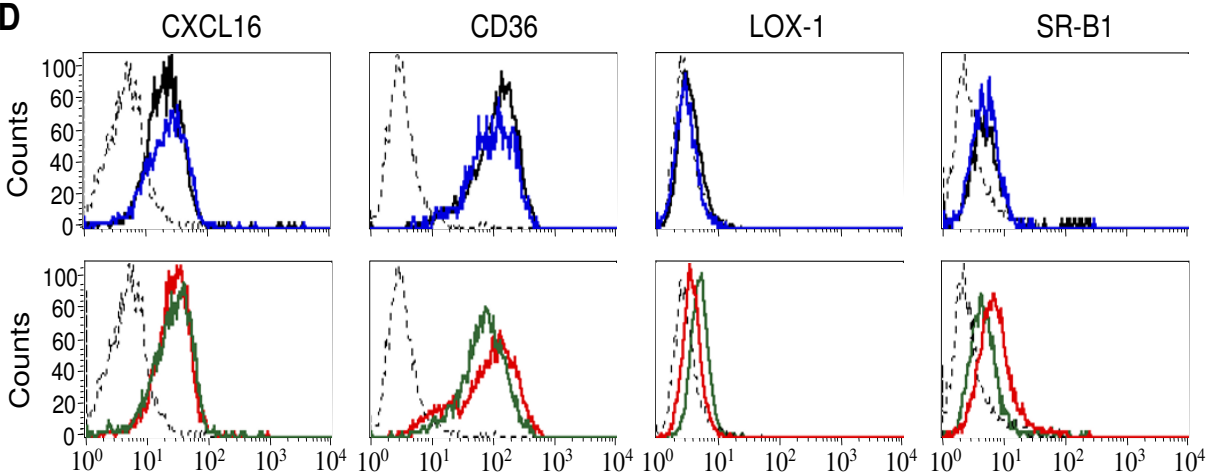

\section{Figure 3}

DEP and PAMP modulate protein expression of Scavenger Receptors in MDDC. MDDC were cultivated with TLR2, -3 and -4 ligands respectively $\operatorname{Pam}_{3} \mathrm{CSK}_{4}(10 \mu \mathrm{g} / \mathrm{ml})$, poly $(\mathrm{l}: \mathrm{C})(10 \mu \mathrm{g} / \mathrm{ml})$ and LPS $(\mathrm{I} \mu \mathrm{g} / \mathrm{ml})$, associated or not with DEP $(10 \mu \mathrm{g} / \mathrm{ml})$. A-B Dendritic cells activated during $6 \mathrm{~h}(\mathrm{~A})$ and $24 \mathrm{~h}(\mathrm{~B})$ were labelled for CD36, CXCLI6, LOX-I and SR-BI, and analyzed by flow cytometry. Data are expressed as the mean \pm SEM from 3 to 7 independent experiments. + : $p<0.05 ;++$ : $p<$ 0.01 compared with unstimulated cells. : $:$ : $p<0,05$ compared with TLR-treated cells. C-D Flow cytometry histograms of a representative experiment. MDDC were cultivated for $6 \mathrm{~h}(\mathrm{C})$ and $24 \mathrm{~h}(\mathrm{D})$ with DEP (blue line), with TLR2 ligand (Pam3CSK4, red line), and with both stimuli (green line) as compared with cells in medium alone (black line). 

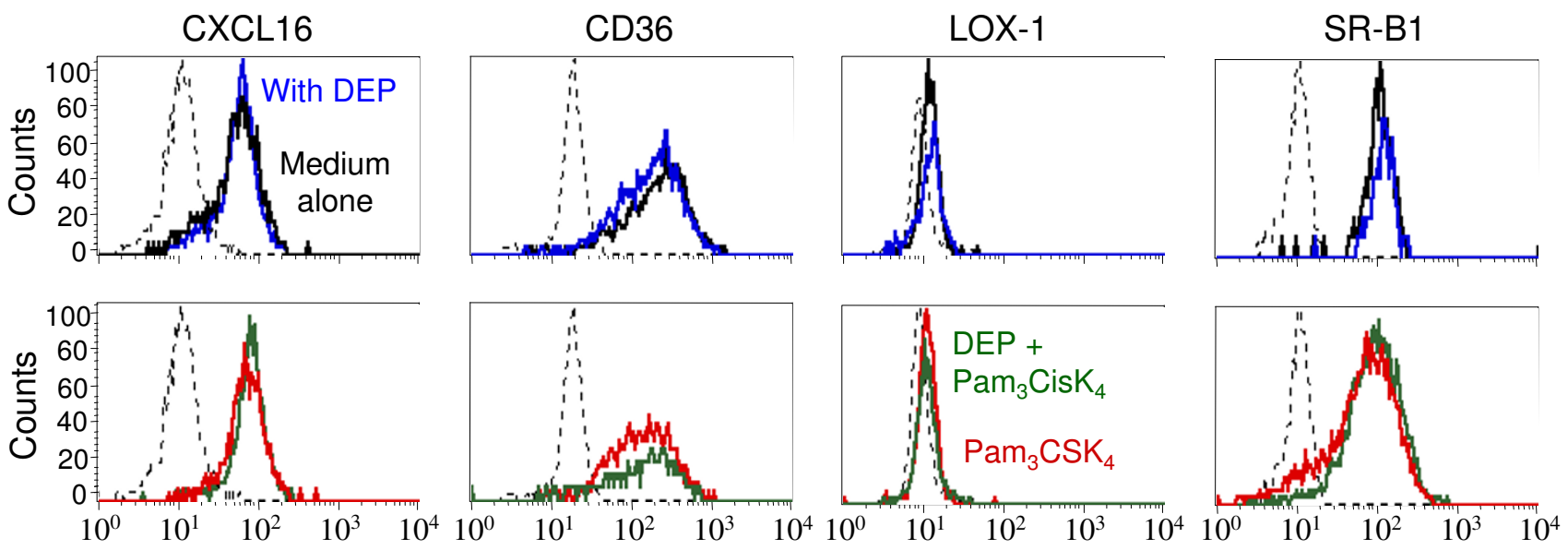

Figure 4

DEP and TLR2 agonist modulate the total protein expression of CD36 and CXCLI6 in MDDC. MDDC were cultivated during $24 \mathrm{~h}$ with DEP (blue line), with TLR2 ligand ( $\mathrm{Pam}_{3} \mathrm{CSK}_{4}$, red line), and with both stimuli (green line) as compared with cells in medium alone (black line). Dendritic cells were labelled after cell permeabilization for CD36, CXCLI6, LOX-I, $\mathrm{SR}-\mathrm{BI}$ and with an isotype control (dotted line) and then, analyzed by flow cytometry.

these SR ligands did not modulate the action of LPS alone on the 3 markers of maturation.

Preincubation with DEP at $1 \mu \mathrm{g} / \mathrm{ml}$ had a weak inhibitory effect on LPS-induced CD83 expression in comparison to LPS alone, whereas HLA-DR and CD86 were not modified. Addition of maleylated-ovalbumin reversed the action of DEP on CD83 expression. Whereas DC-SIGN expression was not affected by DEP treatment, these particles have an additive effect on the LPS-induced decrease of the Mannose Receptor expression (data not shown). Addition of SR ligands did not antagonize this activity (data not shown).

Taken together, these data confirmed that DEP modified the phenotype of LPS-induced matured MDDC, whereas SR ligands blocked the effects of DEP.

\section{Modulation by DEP of LPS-induced cytokine and chemokine production by MDDC: effect of SR ligands}

The involvement of SR in the effect of DEP on LPSinduced cytokine and chemokine secretion by MDDC was also studied. Activation by LPS alone increased the production of CXCL10/IP-10, IL-6, IL-10, IL-12p70 and TNF$\alpha$ (Fig 6) whereas DEP alone had no effect (data not shown). Dextran sulfate (but not maleylated ovalbumin) strongly inhibited the LPS-induced production of IL-10 whereas addition of SR ligands did not significantly modulate the other cytokines.
Preincubation with low dose $(1 \mu \mathrm{g} / \mathrm{ml})$ of DEP significantly increased the LPS-induced production of CXCL10/ IP-10, TNF- $\alpha$, IL-6 and IL-12p70 ( $<$ 0.05). Maleylatedovalbumin strongly inhibited the production of CXCL10/ IP-10 (p < 0.001), IL-12 ( $p<0.05)$ and TNF- $\alpha(\mathrm{p}<0.05)$ induced by low dose of DEP, whereas dextran sulfate had no significant activity. Surprisingly, IL-6 secretion was not modified by treatment with SR ligands. Preincubation with high dose of DEP did not have any significant effect.

Coincubation with low dose of DEP significantly increased CXCL10 production induced by LPS ( $<<0.05)$, a modulation which is antagonized by treatment with both SR ligands, dextran sulfate $(\mathrm{p}<0.05)$ and maleylated ovalbumin $(p<0.001)$. In contrast, simultaneous addition of LPS and the highest dose $(10 \mu \mathrm{g} / \mathrm{ml})$ of DEP inhibited the production of CXCL10 and IL-12 in comparison with LPS alone. Nevertheless, the addition of SR ligands did not neutralize this effect. Preincubation and simultaneous treatment with DEP with and without maleylatedovalbumin had any effect on IL-10 synthesis (Fig 6).

Taken together, these data showed that low dose of DEP increased the synthesis of cytokines by LPS-stimulated DC, whereas the exposure to high dose was able to inhibit CXCL10 and IL-12 production. Preincubation with maleylated-ovalbumin mainly blocked the effect of low dose of DEP but did not antagonize the activity of the high dose. 

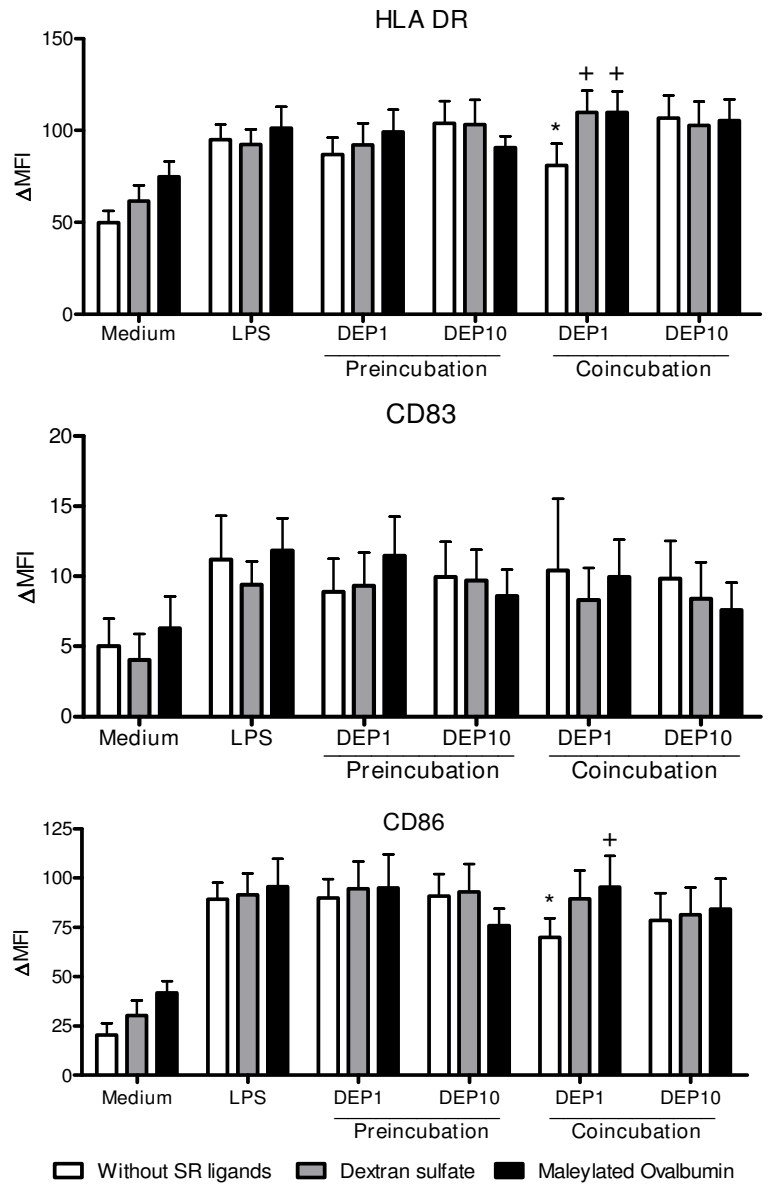

\section{Figure 5}

DEP modulate LPS-induced MDDC maturation: effect of SR ligands. MDDC were preincubated $2 \mathrm{~h}$ with $20 \mu \mathrm{g} / \mathrm{ml}$ dextran sulfate, $100 \mu \mathrm{g} / \mathrm{ml}$ maleylated ovalbumin associated or not with I or $10 \mu \mathrm{g} / \mathrm{ml}$ DEP and then, I $00 \mathrm{ng} /$ $\mathrm{ml}$ LPS were added (Preincubation). For the coincubation, the three ligands are added simultaneously. After $24 \mathrm{~h}$ incubation, MDDC were labeled for HLA-DR, CD83 and CD86 and were analyzed by flow cytometry. Data are expressed as the mean \pm SEM from 7 independent experiments. $*$ : $p<$ 0.05 compared with LPS-treated cells. $+: p<0.05$ compared with the condition without SR ligand.

\section{Effect of DEP on DEP endocytosis and ROS production by DC}

In order to elucidate the action mechanism of SR ligands, endocytosis of DEP by MDDC has been evaluated. The uptake of particles induced an increase in the granularity of the cells, which led to a greater scattering of the laser light in flow cytometry [24]. This is confirmed by our data reported in figure 7 showing that exposure to DEP slightly but significantly $(\mathrm{p}<0.05)$ increased side scatter $(\mathrm{SC})$ in DC. Preincubation with maleylated-ovalbumin but not with dextran sulfate dose dependently inhibited the uptake of DEP $(p<0.05)$.

Since exposure to DEP secondarily induced generation of ROS involved in the modulation of DC functions [12], production of these metabolites by MDDC has been evaluated. At steady state, MDDC produced low level of ROS, as measured by flow cytometry. Activation of PMA significantly increased the generation of ROS which reached its maximum at $2 \mathrm{~h}(\mathrm{p}<0.05)$. DEP significantly increased ROS production after $4 \mathrm{~h}$ stimulation $(\mathrm{p}<0.05)$, whereas this treatment had a weak effect at $2 \mathrm{~h}$ (fig $8 \mathrm{~A}$ ). On the left histogram, treatment with DEP (bold line) induced a strong gap at $4 \mathrm{~h}$ (about $40 \%$ of the $\triangle \mathrm{MFI}$ obtained with PMA).

We also analyzed the capacity of maleylated-ovalbumin to modulate the DEP-induced ROS generation (Fig 8B). Maleylated-ovalbumin had no significant effect on DEPinduced ROS production observed after $4 \mathrm{~h}$ stimulation.

\section{Discussion}

There is growing evidence that inhaled particulate matter derived from diesel contributes to the increased incidence of allergic diseases, respiratory infections and mortality $[1,5-7,9]$. The effect of DEP on lung immune response probably implicated the modulation of pulmonary DC functions.

In this study, we assessed whether DEP may affect the expression and the function of SR and by this way, can modulate the function of DC during activation by TLR ligands. Indeed, TLR ligands are frequently associated with airborne particles [23]. Here we showed that DEP modulate the activity of TLR ligands on SR expression in DC. Moreover, pretreatment with SR ligands blocks some effects of DEP on LPS-induced DC maturation and cytokine production through a still unknown mechanism.

Within airway mucosa, particulate matter-exposed bronchial epithelial cells secrete the DC chemoattractant CCL20/MIP-3 $\alpha$, CCL2/MCP-1, and CCL5/RANTES [25]. Therefore, one might expect that DC would be among the first cells to interact with inhaled particulate matter. In the current study, we used well-established protocols that are thought to yield immature MDDC representative of those present in vivo at mucosal sites [26]. Since respiratory tract DC are rapidly derived from circulating precursors $[27,28]$, we believe our experiments provide a reasonable approximation of how DC and DEP interact in vivo. In addition, DC can insert dendrites between airway epithelial cells to directly capture the particle or microorganism within the airway lumen [29]. 

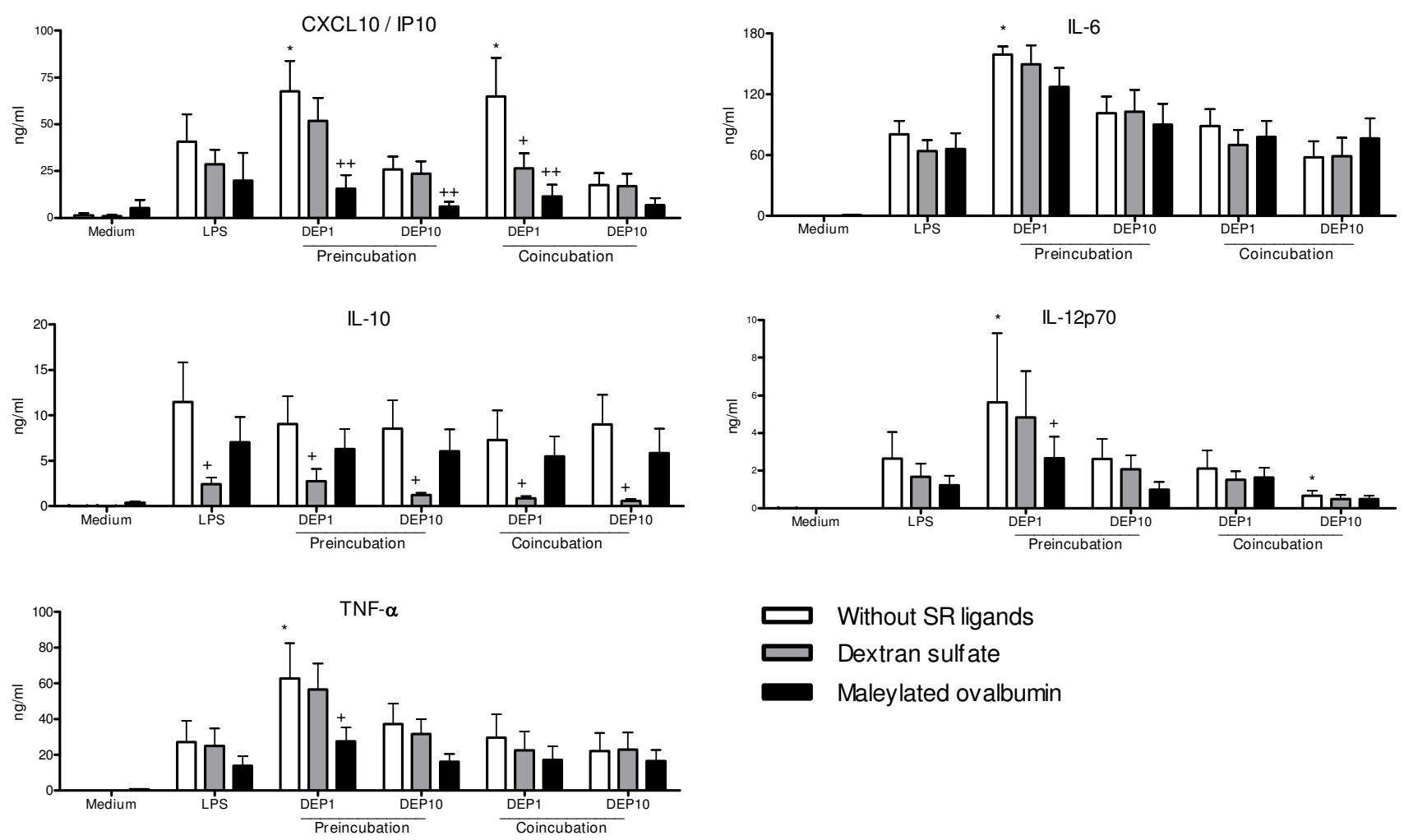

Figure 6

DEP modulate LPS-induced cytokine and chemokine production by MDDC: effect of SR ligands. MDDC were preincubated $2 \mathrm{~h}$ with $20 \mu \mathrm{g} / \mathrm{ml}$ dextran sulfate, $100 \mu \mathrm{g} / \mathrm{ml}$ maleylated ovalbumin associated or not with I or $10 \mu \mathrm{g} / \mathrm{ml} \mathrm{DEP}$ and then, $100 \mathrm{ng} / \mathrm{ml}$ LPS were added (Preincubation). For the coincubation, the three ligands are added simultaneously. After $24 \mathrm{~h}$ incubation, the concentrations of IP-I0, IL-I2, IL- 6 and TNF- $\alpha$ were measured by ELISA. Data are expressed as the mean \pm SEM from 8 independent experiments. $;: p<0.05$ compared with LPS-treated cells. $+: p<0.05 ;++: p<0.01$ compared with the condition without SR ligand.

\section{Modulation of SR expression}

There are few studies about the regulation of the expression of SR on DC. Concerning the regulation of class-A SR in DC, Amiel et al showed that SR-A expression is upregulated during DC maturation, and is correlated with the expression of the murine DC marker CD11c [30]. Another study showed that advanced glycosylation end (AGE)-BSA upregulated SR-A expression on DC via MAP kinases pathway (Jnk) [31]. The last work showed the upregulation of SR-B1 during the differentiation of MDDC. SR-B1 expression was suppressed by LPS, IFN- $\gamma$ and TNF- $\alpha$ in monocytes and macrophages [32]. In the same way, we detect a transient decrease of SR-B1 expression in LPS-stimulated MDDC. We have also evaluated on MDDC the protein expression of MARCO, a SR involved in the particle clearance within the lung. Using a mAb (PLK1 clone; HBT, Uden, The Nederlands), our data revealed that this SR is nearly undetectable on MDDC by flow cytometry after intracellular and extracellular labeling, whatever the condition of stimulation (data not shown).

In this study, the selection of the five SR is based on their expression in airway mucosa particularly in airway epithelium and in MDDC (data not shown). In addition, these receptors are known to be implicated in the modulation of TLR activity [33-36]. Our results showed that DEP had a weak effect on the SR mRNA expression, in contrast with the strong effect induced by TLR2 and TLR4 ligands. However, DEP alone seems to decrease the protein expression of CD36 and SR-B1 suggesting their mobilization during their interaction with DEP. In contrast, TLR2 ligand and at a lower level, TLR4 agonist enhances both the mRNA and protein expression of LOX-1, CXCL16 and SR-B1. Concerning SR-A1 and CD36, there is a clear dissociation between the TLR-dependent modulation of mRNA (increased) and protein (decreased) expression suggesting 


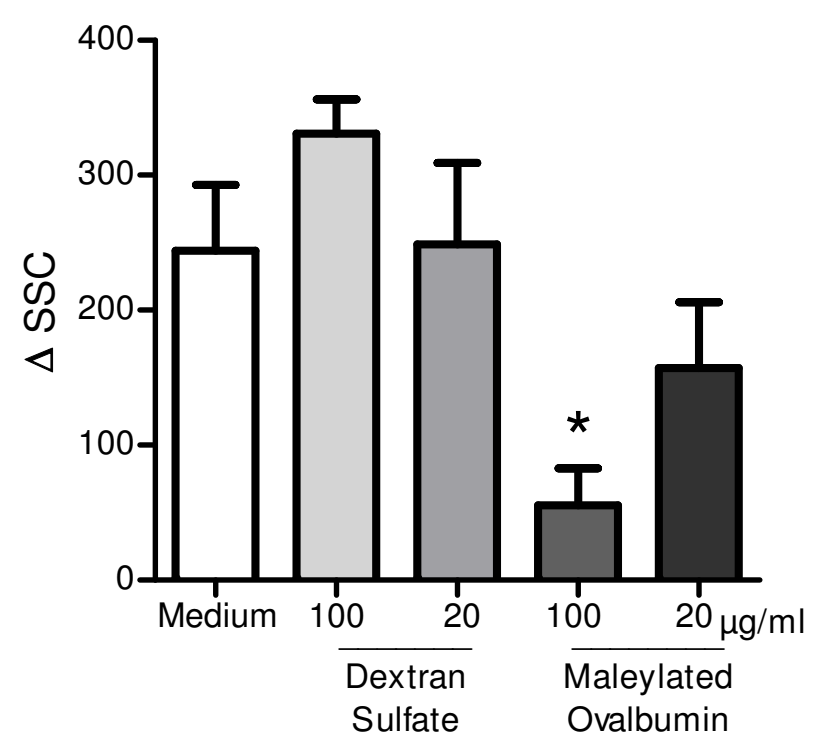

Figure 7

SR ligands modulate DEP endocytosis. MDDC were preincubated for $15 \mathrm{~min}$ with 20 and $100 \mu \mathrm{g} / \mathrm{ml}$ dextran sulfate or maleylated ovalbumin and then, DEP $(10 \mu \mathrm{g} / \mathrm{ml})$ was added. After $6 \mathrm{~h}$ incubation, side scatter (SSC) of MDDC was analyzed by flow cytometry. Data are expressed as the difference between the SSC in DEP-stimulated and inactivated cells. The data reported the mean \pm SEM from 5 independent experiments. : $: \mathrm{p}<0.05$ compared with cells with DEP alone (medium).

that their membrane expression in DC are mainly controlled by post-transcriptional mechanisms as previously reported [20]. Measurement of intracellular expression revealed that the level of CD36 and CXCL16 is parallel in both extracellular and intracellular compartment whereas this is not true for LOX-1 and SR-B1. According to these data, the mechanisms controlling the membrane expression of LOX-1 and SR-B1 are probably very different from those of CD36 and CXCL16. Since TLR3 activation had a weak effect on SR level in contrast to TLR2 and TLR4, we can suspect that MyD88-dependent pathway mobilized by both TLR is involved in the modulation of SR expression. Associated with pathogen-associated molecular pattern (PAMP), DEP modulate the activity of TLR2 and TLR4 ligands according to the SR. As previously reported [1012], DEP can modulate the signalling pathways activated by TLR and by this way, controlled the modulation of SR expression. In addition, we can suspect that DEP uptake by MDDC directly mobilizes some SR such as CD36 and SR-B1 and interferes with the activity of TLR agonists on SR expression.

\section{Regulation of DC maturation induced by TLR ligand}

There are some controversial data in the literature concerning the impact of DEP exposure on DC maturation. Most studies show that DEP alone have no effect on DC maturation whereas it can act as an adjuvant in order to increase the response to an allergen or a TLR ligand [10]. In contrast, DEP can also inhibit some signals induced by TLR activation and deviate the phenotype of mature DC towards a pro-Th2 type. Indeed, DEP inhibit IL-12 mRNA and protein expression in DC, and decrease IFN- $\gamma$ production by T lymphocytes cocultured with DEP-exposed DC [11]. DEP in mice inhibited DC maturation (IL-12 production and co-stimulatory molecule expression) induced by TLR2, 3, 4 and 9 ligands [12]. Finally, another report also suggests that direct exposure to airborne particulate matter from diesel vehicles increased the expression of MHC class II and costimulatory molecules and the production of TNF- $\alpha$, IL-12p40, IL-6, and VEGF [2].

In our model, DEP alone have no effect on DC maturation, suggesting that their effect on MDDC is dependent upon their origin and their preparation (addition of surface activator or surfactant) as previously reported [37]. In our hands, DEP modulate the LPS-induced DC maturation according to the timing and to the dose. We show that the low dose of DEP increases the synthesis of cytokine by LPS-stimulated DC, whereas the high dose blocks IP-10 and IL-12 production. Moreover, SR ligands are able to reverse some effects of DEP. One hypothesis to explain these data might be that there is a competition for the uptake and internalization of DEP. Our results demonstrated that mOva but not dextran sulfate inhibited in a dose-dependent manner the uptake of DEP. This suggests that it is not the only mechanism involved in the activity of poly-specific SR ligands. The fact that SR agonists only block the action of low dose of DEP, can be explained by an insufficient molecular ratio between SR ligands and DEP in order to inhibit the effect of the high dose. Another explanation might be that, according to the dose, different receptors are implicated in the DEP effect. This hypothesis is likely since both doses of DEP have an opposite effect on cytokine secretion by DC. The implication of the xenobiotic sensor AhR has been previously mentioned [38]. Moreover, SR are also described as coreceptors for TLR, DEP can interfere with TLR-induced signalling through the mobilization of SR. For example, activation with the TLR2 ligand Kp-OmpA is dependent of both SREC-1 and LOX-1 or with diacylglycerides, of CD36 $[34,39]$. CD36, with established roles in recognition of endogenous and exogenous ligands, facilitates TLR2 signaling [40]. In addition, CXCL16 is involved in TLR9 activation by plasmacytoid DC [33]. Preincubation with maleylated-ovalbumin mainly block all the effects of low dose of DEP whereas dextran sulfate have a more restricted effect. Maleylated OVA binds to most of the SR, 

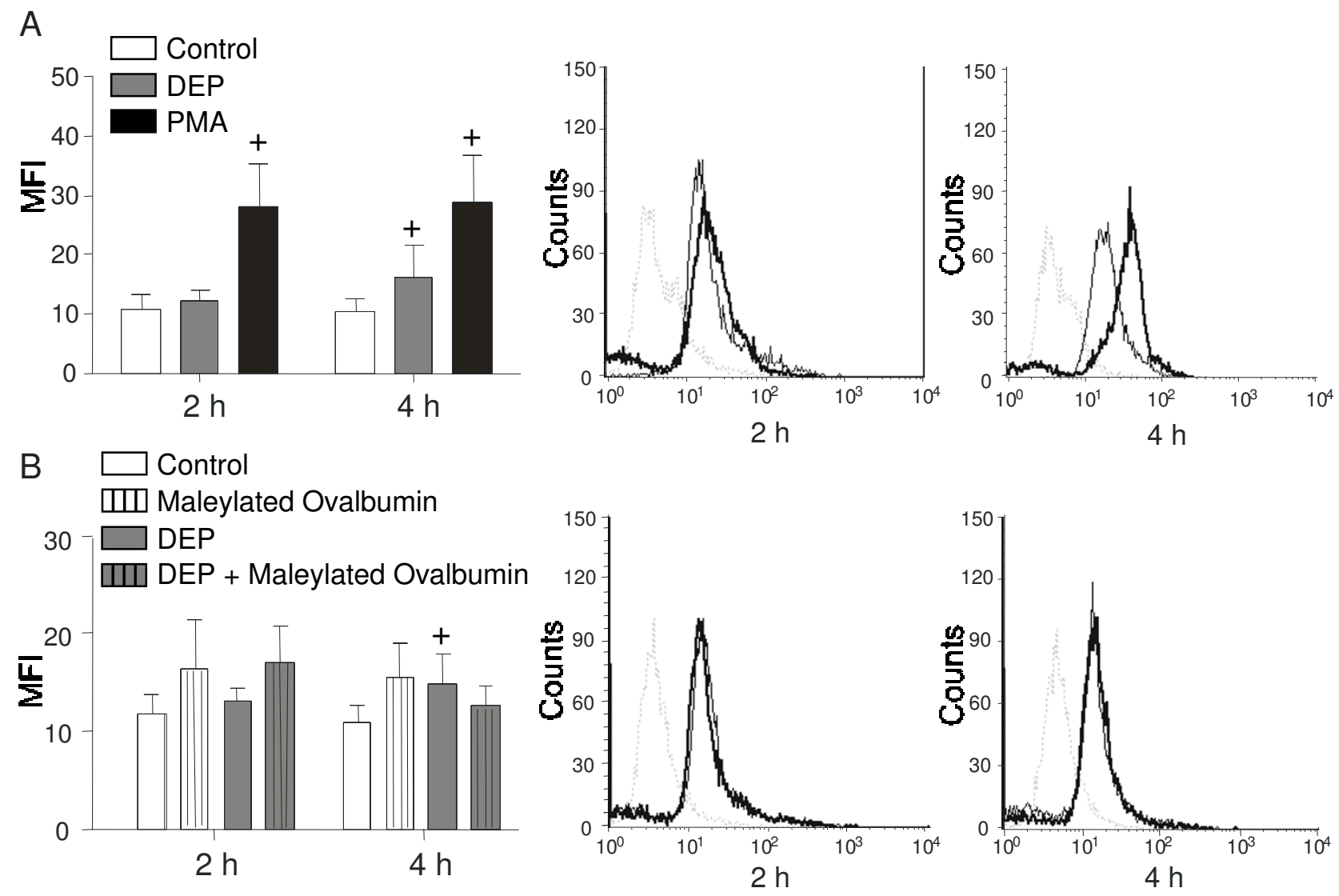

\section{Figure 8}

Effect of DEP on ROS production by MDDC. A. MDDC were incubated in medium alone, with DEP (I0 $\mu \mathrm{g} / \mathrm{ml})$ or with PMA (I00 ng/ml) for different time periods. ROS production was analyzed by flow cytometry. The left histogram reported the mean \pm SEM from 6 independent experiments whereas the flow cytometry histograms show the data obtained in one representative experiment. +: $p<0.05$ compared with cells in medium alone. B. Modulation by maleylated ovalbumin of DEP effect on MDDC activated for 2 and $4 \mathrm{~h}$. Data in the left histogram are expressed as the mean \pm SEM from 6 independent experiments. The flow cytometry histograms reported the data obtained in one representative experiment. $+: p<0.05$ compared with cells in medium alone.

including the class II scavenger receptors SR-AI/II, SR-BI and CD36 [20]. Moreover, we have observed that $\mathrm{CHO}$ cells expressing either CXCL16, LOX-1 or SREC-1 strongly bind FITC-conjugated maleylated OVA (data not shown). Dextran sulfate has been reported to inhibit the binding of several ligands to SR-AI/II, SREC-I, CXCL16 and LOX-1 [41] whereas this ligand does not interact with CD36 [42]. Moreover, sulfated glyconconjugates, including dextran sulfate, share a binding inhibition pattern consistent with class A or C activity [43]. According to our data, we can suspect that class B SR (SR-B1, CD36) are presumably involved within DEP effect in DC. To confirm the implication of SR, it would be interesting to test other inhibitory methods like gene silencing.

The modulation of IL-12 and CXCL10 production (two major cytokines involved in the differentiation and the recruitment of Th1 cells) by SR ligands may have a strong impact on the capacity of DEP-exposed DC to polarize the $\mathrm{T}$ cell response. Since this effect is only observed at low doses, we can suspect that it is mainly involved in the long term effect of chronic exposure to these particles.

\section{DEP effect on DC phenotype}

Our data demonstrate that coincubation with LPS and DEP affects the phenotype of mature $\mathrm{DC}$, decreasing the expression of the costimulatory molecule CD86 and of the HLA-DR molecule. We demonstrate that this effect is dependent on SR mobilization. This process could impact the T cell response and polarization since CD86 is known to be implicated in Th2 cell development.

Recently, Porter et al demonstrate that airborne particulate matter from diesel vehicles enhanced the MR expression 
and potentialized antigen uptake (dextran-FITC) whereas LPS decreased both MR expression and antigen uptake [2]. In the present study, DEP alone had no effect on MR expression (data not shown) whereas it had an additive effect on the LPS-induced decrease of this receptor. As underlined above, this discrepancy is probably related to different origins of the particles.

\section{ROS production}

It has been demonstrated in human and murine models that the effects of DEP on DC are associated with ROS production $[11,12]$. Notably, DEP-induced ROS production triggers the activation of a signaling pathway mediated by nuclear factor-erythroid 2 (NF-E2)-related factor 2 that suppresses IL-12 production [12]. In our model, the inhibition of IL-12 production as well as ROS production are only detected at high concentrations of DEP and both seem to be independent of SR mobilization. These data strongly suggest that the activation of NF-E2 in not dependent of SR-induced signalling pathways. At the opposite, SR seems to be involved in the upregulation of the cytokine production triggered by the low dose of DEP.

\section{Conclusion}

Taken together, our results show that the modulation of DC functions by DEP involves the mobilization of SR. Moreover, the impact on DC functions appears to be different according to the dose and probably implicates different signalling pathways. Interfering with the expression and/or the function of SR might be one way to limit the impact of DEP on lung immune response and on the induction and the exacerbation of lung diseases.

\section{Methods \\ Preparation of DEP}

We used standard DEP (standard reference material (SRM) 2975) obtained from the National Institute for Standards and Technology (NIST, Gaithersburg, USA). The material was collected from a filtering system designed specifically for diesel-powered forklifts. Its chemical composition is mentioned in the Certificate of Analysis from NIST. DEP were diluted in a solution containig 0,04\% Dipalmitoyl Phosphatidylcholin (Fluka Chemie, Buchs, Switzerland). To minimize aggregation, DEP were sonicated for 15 minutes and shaked prior to their dilution. The suspension was diluted in culture medium to the final concentrations required for exposure of the cells.

\section{Preparation of MDDC and DEP exposure}

Blood monocytes from healthy volunteers were purified by positive selection over a MACS column using antiCD14-monoclonal antibodies (mAb) conjugated microbeads (Miltenyi Biotec GmBH, Bergisch Gladbach, Germany) and were differentiated into dendritic cells by standard procedures [26]. Briefly, monocytes were cultivated at $1 \times 10^{6}$ cells $/ \mathrm{ml}$ for 5 days in RPMI 1640 supplemented with $10 \%$ heat-inactivated FCS (Invitrogen, Paisley, UK) containing $10 \mathrm{ng} / \mathrm{ml} \mathrm{IL-4}$ and $25 \mathrm{ng} / \mathrm{ml}$ GMCSF (PromoCell, Heidelberg, Germany).

At day 5, CD14-CD11 ${ }^{+}$HLA-DR ${ }^{\text {low }}$ immature monocytederived DC were obtained as characterized by their phenotype and the low level of cytokine production (data not shown).

Cells were either left untreated or were exposed for 1, 3, 6, 8 or $24 \mathrm{~h}$ to DEP $(10 \mu \mathrm{g} / \mathrm{ml})$ with or without the TLR2 ligand Pam3CSK4 $(10 \mu \mathrm{g} / \mathrm{ml})$, the TLR3 ligand poly(I:C) (10 $\mu \mathrm{g} / \mathrm{ml}$ ) or the TLR4 ligand LPS $(1 \mu \mathrm{g} / \mathrm{ml})$ (Invivogen, San Diego, CA) depending on the experiments. The vehicle for DEP containing $0.04 \%$ dipalmitoyl phosphatidylcholin was added in the control wells.

To evaluate their maturation in the presence of DEP, the activation protocol was as follows: MDDC were preincubated with the SR ligands Dextran sulfate $(20 \mu \mathrm{g} / \mathrm{ml})$ or maleylated- and deglycosylated ovalbumin $(100 \mu \mathrm{g} / \mathrm{ml})$ with or without DEP ( 1 or $10 \mu \mathrm{g} / \mathrm{ml}$ ) during $2 \mathrm{~h}$ before addition of LPS $(100 \mathrm{ng} / \mathrm{ml})$ for $24 \mathrm{~h}$. In some experiments, the SR ligands, DEP and LPS were added at the same time. The preparation of SR ligands are endotoxinfree, as measured by the limulus amebocyte assay (Lonza, Verviers, Belgium). As previously described, dextran sulfate particularly targets SREC-1 and CXCL16 whereas maleylated-ovalbumin binds to most of the SR [44-46]. Cell viability was evaluated in each condition of activation by trypan blue exclusion after $24 \mathrm{~h}$ incubation and no significant decrease was detected in the presence of each activator or their combination.

\section{Real Time quantitative PCR}

Total RNA was isolated from DC exposed to DEP and/or to TLR ligands. After 1 or $3 \mathrm{~h}$ incubation, cells were washed in sterile cold PBS, lysated by using TRIzol reagent (Invitrogen) and RNA were isolated according to manufacturer's instructions. RNA concentration was determined by spectrophotometry and its quality was evaluated by electrophoresis through a $0.8 \%$ agarose gel visualized using Gelstar staining. Retro-transcription and Real-Time quantitative PCR were performed using SuperScript $^{\mathrm{TM}}$ Platinum ${ }^{\circledR}$ SYBR $^{\circledR}$ Green Two-Step qRT-PCR Kit with ROX (Invitrogen, Paisley, Scotland) according to manufacturer's instructions. Forty-five cycles of cDNA amplification were performed at $55^{\circ} \mathrm{C}$ (30s) after hybridation at $60^{\circ} \mathrm{C}(20 \mathrm{~s})$. In order to obtain a normalized target value, the house-keeping gene actin was used. Forward and reverse primers for CD36, CXCL16, Lox-1 and SR-B1 were designed as follows: CD36 (forward 5'-TGTCCGCGAAGAAGGTACAA, reverse 5'-TCACTTCCTGT- 


\begin{abstract}
GGATTTTGCAC); CXCL16 (forward 5'GGCTTTGGACCCTTGTCTCTTG, reverse 5'-TTGCGCTGGACACAATTACGCCAGGT, reverse 5'ATCTGCCCTTCCAGGATACGA); SR-A1 (forward 5'TTCAAAGCTGCACTGATTGCC, reverse 5'-TTCTTCGTTTCCCACTTCAGGA); SR-B1 (forward 5'-TGACGATCCCTTCGTGCATT, reverse 5'-CATCCCAACAAACAGGCCAA); actin (forward 5'-TCCTCACCCTGAAGTACCCCA, reverse 5'-AGCCACACGCAGCTCATTGT).
\end{abstract}

Results were expressed mean $+/$ - SEM of the relative gene expression calculated for each experiment in folds (2 $(\Delta \Delta \mathrm{Ct}))$ compared to unstimulated cells used as calibrator.

\section{Chemokine and cytokine measurements}

The concentrations of cytokines and chemokines in the culture supernatants were determined by sandwich enzyme immunoassay as described by the manufacturer, R\&D systems for CXCL10/IP-10, IL-6, and TNF- $\alpha$ or Diaclone (Besançon, France) for IL-12p70.

\section{Flow cytometry}

After the recovery of MDDC supernatants, cells were incubated with PBS/EDTA $(2 \mathrm{mM})$ and were detached by scraping. MDDC were centrifuged and resuspended in PBS containing $2 \%$ FCS. Cells were labeled $\left(30 \mathrm{~min}, 4^{\circ} \mathrm{C}\right)$ with murine FITC-conjugated anti HLA-DR and DC-SIGN mAb, PE-conjugated anti CD80, CD83 and Mannose Receptor mAb, APC-conjugated anti CD86 and CD11c $\mathrm{mAb}$ or mouse IgG isotype controls conjugated with FITC, PE or APC (BD Pharmingen, except for CD83 from Beckman Coulter). Cells were washed with cold PBS and fixed with $1 \%$ paraformaldehyde in PBS.

To study SR expression, cells were labelled $\left(30 \mathrm{~min}, 4^{\circ} \mathrm{C}\right)$ with mouse anti-LOX-1 (HBt), -SR-B1 (BD) and -CD36 (Labvision), goat anti-CXCL16 (R\&D systems) antibodies or the relevant isotype control. Binding of unlabelled $\mathrm{Ab}$ or isotype control was detected by addition of FITC-conjugated anti-mouse or PE-conjugated anti-goat IgG antibodies (Invitrogen). In some experiments, the procedure was reproduced with cells previously fixed and permeabilized according to the procedure of the kit manufacturer (BD Biosciences). For SR-A1, cells were directly labelled with an FITC-conjugated anti-SR-A1 monoclonal antibody (R\&D Systems). Then, cells were washed, fixed with paraformaldehyde in PBS and 10000 events were analyzed on a FACScalibur flow cytometer with CellQuest software (Becton Dickinson). Results are expressed as the difference between median fluorescence intensity (MFI) with specific antibody minus the isotype control MFI $(\Delta \mathrm{MFI})$.

\section{Analysis of oxidative metabolism}

$10 \mu \mathrm{M}$ of H2DCFDA (Dihydro-DichloroFluorescein Diacetate) was added to $2 \times 10^{5}$ DC cultured in PBS for 30 minutes before stimulation with DEP $(10 \mu \mathrm{g} / \mathrm{ml})$ associated or not with SR ligand maleylated-ovalbumine, positive control PMA $(100 \mathrm{ng} / \mathrm{ml})$ for 2 and $4 \mathrm{~h}$. ROS generation was quantified by Flow Cytometry. Results are expressed as the difference between median fluorescence intensity (MFI) with DCFDA minus the autofluorescence control MFI $(\triangle \mathrm{MFI})$.

\section{Statistical analysis}

Results are expressed as the mean \pm SEM. The statistical significance of the differences between experimental groups was calculated by ANOVA1 with a Bonferroni post test (GraphPad Prism 4 Software, San Diego, USA). Results with a $P$ value of less than 0.05 were considered significant.

\section{Abbreviations}

Ag: Antigen; DC: Dendritic Cell; DEP: Diesel Exhaust Particle; mDC: Myeloid Dendritic Cell; MDDC: MonocyteDerived Dendritic Cell; MFI: Median of fluorescence intensity; mOVA: maleylated ovalbumin; mRNA: Messenger Ribonucleic Acid; LPS: Lipopolysaccharide; PAMP: Pathogen-Associated Molecular Pattern; PMA: Phorbol Myristate Acetate; ROS: Reactive Oxygen Species; RSV: Respiratory Syncytial Virus; SR: Scavenger Receptor; TLR: Toll-Like Receptor.

\section{Competing interests}

The authors declare that they have no competing interests.

\section{Authors' contributions}

TS had performed and analyzed most of the data, had designed the study and wrote the article with PG. DA had participated to the cell culture experiments, to the QRTPCR experiments and to the collection of data; she had also contributed to the design of the study. BS, JP and DY had participated to the development of the methodologies regarding the expression of SR and to the revising of the article. They also prepared the SR ligands and evaluated their binding to $\mathrm{CHO}$ cells. PhL contributed to the design and conception of the study and to the revising of the article. PG had acted as the main contributor for the design and the conception of the study. He had also coordinated the study. All authors have read and approved the final manuscript.

\section{Acknowledgements}

ST was supported by a grant from Agence de l'Environnement et de la Maitrise de l'Energie (ADEME) and Conseil Régional Nord-Pas-De-Calais. We would like to thank Isabelle Fremaux for her help in the correction of the manuscript. 


\section{References}

I. Ebtekar M: Air pollution induced asthma and alterations in cytokine patterns. Iran J Allergy Asthma Immunol 2006, 5(2):47-56

2. Porter M, Karp M, Killedar S, Bauer SM, Guo J, Williams D, Breysse $\mathrm{P}$, Georas SN, Williams MA: Diesel-enriched particulate matter functionally activates human dendritic cells. Am J Respir Cell Mol Biol 2007, 37(6):706-7I9.

3. Riedl M, Diaz-Sanchez D: Biology of diesel exhaust effects on respiratory function. J Allergy Clin Immunol 2005, I I 5(2):22 I-228. quiz 229.

4. Sydbom A, Blomberg A, Parnia S, Stenfors N, Sandstrom T, Dahlen SE: Health effects of diesel exhaust emissions. Eur Respir J 200 I, I 7(4):733-746.

5. Miyabara Y, Ichinose T, Takano H, Lim HB, Sagai M: Effects of diesel exhaust on allergic airway inflammation in mice. J Allergy Clin Immunol 1998, I02(5):805-8I2.

6. Takano H, Yoshikawa T, Ichinose T, Miyabara Y, Imaoka K, Sagai M: Diesel exhaust particles enhance antigen-induced airway inflammation and local cytokine expression in mice. Am Respir Crit Care Med 1997, I 56(I):36-42.

7. Diaz-Sanchez D, Tsien A, Fleming J, Saxon A: Combined diese exhaust particulate and ragweed allergen challenge markedly enhances human in vivo nasal ragweed-specific IgE and skews cytokine production to a $\mathrm{T}$ helper cell 2-type pattern. J Immunol 1997, I 58(5):2406-24I 3.

8. Jaspers I, Ciencewicki JM, Zhang W, Brighton LE, Carson JL, Beck MA, Madden MC: Diesel exhaust enhances influenza virus infections in respiratory epithelial cells. Toxicol Sci 2005, 85(2):990-1002.

9. Harrod KS, Jaramillo RJ, Rosenberger CL, Wang SZ, Berger JA, McDonald JD, Reed MD: Increased susceptibility to RSV infection by exposure to inhaled diesel engine emissions. American journal of respiratory cell and molecular biology 2003, 28(4):45 I-463.

10. Verstraelen S, Van Den Heuvel R, Nelissen I, Witters H, Verheyen G, Schoeters G: Flow cytometric characterisation of antigen presenting dendritic cells after in vitro exposure to diesel exhaust particles. Toxicol In Vitro 2005, I 9(7):903-907.

II. Ohtani T, Nakagawa S, Kurosawa M, Mizuashi M, Ozawa M, Aiba S: Cellular basis of the role of diesel exhaust particles in inducing Th2-dominant response. J Immunol 2005, I 74(4):24I 2-24I9.

12. Chan RC, Wang M, Li N, Yanagawa Y, Onoe K, Lee J], Nel AE: Prooxidative diesel exhaust particle chemicals inhibit LPSinduced dendritic cell responses involved in T-helper differentiation. J Allergy Clin Immunol 2006, I I 8(2):455-465.

13. Holt PG, Stumbles PA: Characterization of dendritic cell populations in the respiratory tract. I Aerosol Med 2000, I3(4):36 I-367.

14. Lambrecht BN, Salomon B, Klatzmann D, Pauwels RA: Dendritic cells are required for the development of chronic eosinophilic airway inflammation in response to inhaled antigen in sensitized mice. J Immunol 1998, I 60(8):4090-4097.

15. McWilliam AS, Napoli S, Marsh AM, Pemper FL, Nelson DJ, Pimm CL, Stumbles PA, Wells TN, Holt PG: Dendritic cells are recruited into the airway epithelium during the inflammatory response to a broad spectrum of stimuli. J Exp Med 1996 , I 84(6):2429-2432.

16. Pichavant M, Charbonnier AS, Taront S, Brichet A, Wallaert B, Pestel J, Tonnel AB, Gosset P: Asthmatic bronchial epithelium activated by the proteolytic allergen Der $p$ I increases selective dendritic cell recruitment. The Journal of allergy and clinical immunology 2005, I I 5(4):77I-778.

17. Vermaelen KY, Carro-Muino I, Lambrecht BN, Pauwels RA: Specific migratory dendritic cells rapidly transport antigen from the airways to the thoracic lymph nodes. J Exp Med 200I, | 93( I):5 1-60.

18. Peiser L, Mukhopadhyay S, Gordon S: Scavenger receptors in innate immunity. Current opinion in immunology 2002, | 4(I): I23-128.

19. Steinman RM, Hemmi H: Dendritic cells: translating innate to adaptive immunity. Curr Top Microbiol Immunol 2006, 3 I I : I 7-58.

20. Murphy JE, Tedbury PR, Homer-Vanniasinkam S, Walker JH, Ponnambalam S: Biochemistry and cell biology of mammalian scavenger receptors. Atherosclerosis 2005, I 82(I): I-I5.

21. Kobzik L: Lung macrophage uptake of unopsonized environmental particulates. Role of scavenger-type receptors. J Immunol 1995, I 55(I):367-376.
22. Arredouani M, Yang Z, Ning Y, Qin G, Soininen R, Tryggvason K, Kobzik L: The scavenger receptor MARCO is required for lung defense against pneumococcal pneumonia and inhaled particles. J Exp Med 2004, 200(2):267-272.

23. Dong W, Lewtas J, Luster MI: Role of endotoxin in tumor necrosis factor alpha expression from alveolar macrophages treated with urban air particles. Exp Lung Res 1996 22(5):577-592.

24. Boland S, Baeza-Squiban A, Fournier T, Houcine O, Gendron MC Chevrier M, Jouvenot G, Coste A, Aubier M, Marano F: Diesel exhaust particles are taken up by human airway epithelial cells in vitro and alter cytokine production. The American journal of physiology 1999, 276(4 Pt I):L604-6I3.

25. Reibman J, Hsu Y, Chen LC, Bleck B, Gordon T: Airway epithelial cells release MIP-3alpha/CCL20 in response to cytokines and ambient particulate matter. Am J Respir Cell Mol Biol 2003, 28(6):648-654.

26. Gosset $P$, Bureau $F$, Angeli $V$, Pichavant $M$, Faveeuw $C$, Tonnel $A B$, Trottein F: Prostaglandin D2 affects the maturation of human monocyte-derived dendritic cells: consequence on the polarization of naive Th cells. J Immunol 2003, I 70( I 0):4943-4952.

27. Vermaelen K, Pauwels R: Pulmonary dendritic cells. Am J Respir Crit Care Med 2005, I 72(5):530-55I.

28. Lambrecht $\mathrm{BN}$, Hammad $\mathrm{H}$ : Taking our breath away: dendritic cells in the pathogenesis of asthma. Nat Rev Immunol 2003 , 3(12):994-1003.

29. Ichiyasu H, McCormack JM, McCarthy KM, Dombkowski D, Preffer FI, Schneeberger EE: Matrix metalloproteinase-9-deficient dendritic cells have impaired migration through tracheal epithelial tight junctions. Am J Respir Cell Mol Biol 2004, 30(6):76 I-770.

30. Amiel E, Nicholson-Dykstra S, Walters J, Higgs H, Berwin B: Scavenger receptor-A functions in phagocytosis of $E$. coli by bone marrow dendritic cells. Exp Cell Res 2007, 3 I3(7): |438-|448.

31. Ge J, Jia Q, Liang C, Luo Y, Huang D, Sun A, Wang K, Zou Y, Chen $\mathrm{H}$ : Advanced glycosylation end products might promote atherosclerosis through inducing the immune maturation of dendritic cells. Arterioscler Thromb Vasc Biol 2005, 25(10):2157-2163

32. Buechler C, Ritter M, Quoc CD, Agildere A, Schmitz G: Lipopolysaccharide inhibits the expression of the scavenger receptor Cla-I in human monocytes and macrophages. Biochem Biophys Res Commun 1999, 262(I):25I-254.

33. Gursel M, Gursel I, Mostowski HS, Klinman DM: CXCLI 6 influences the nature and specificity of CpG-induced immune activation. I Immunol 2006, I 77(3): I575-1580.

34. Jeannin P, Bottazzi B, Sironi M, Doni A, Rusnati M, Presta M, Maina V, Magistrelli G, Haeuw JF, Hoeffel G, et al.: Complexity and complementarity of outer membrane protein A recognition by cellular and humoral innate immunity receptors. Immunity 2005 , 22(5):55 I-560.

35. Stuart LM, Deng J, Silver JM, Takahashi K, Tseng AA, Hennessy EJ, Ezekowitz RA, Moore KJ: Response to Staphylococcus aureus requires CD36-mediated phagocytosis triggered by the COOH-terminal cytoplasmic domain. J Cell Biol 2005 , I 70(3):477-485.

36. Triantafilou M, Gamper FG, Haston RM, Mouratis MA, Morath S, Hartung $\mathrm{T}$, Triantafilou $\mathrm{K}$ : Membrane sorting of toll-like receptor (TLR)-2/6 and TLR2/I heterodimers at the cell surface determines heterotypic associations with CD36 and intracellular targeting. The Journal of biological chemistry 2006, 28I(4I):3 I002-3।0II.

37. Singh P, DeMarini DM, Dick CA, Tabor DG, Ryan JV, Linak WP, Kobayashi T, Gilmour MI: Sample characterization of automobile and forklift diesel exhaust particles and comparative pulmonary toxicity in mice. Environ Health Perspect 2004, I | 2(8):820-825.

38. Vogel CF, Sciullo E, Wong P, Kuzmicky P, Kado N, Matsumura F: Induction of proinflammatory cytokines and $C$-reactive protein in human macrophage cell line $\mathbf{U} 937$ exposed to air pollution particulates. Environ Health Perspect 2005 , I I3(II):|536-|54|.

39. Hoebe K, Georgel P, Rutschmann S, Du X, Mudd S, Crozat K, Sovath $S$, Shamel L, Hartung T, Zahringer U, et al.: CD36 is a sensor of diacylglycerides. Nature 2005, 433(7025):523-527.

40. Bjorkbacka $\mathrm{H}$ : Multiple roles of Toll-like receptor signaling in atherosclerosis. Current opinion in lipidology 2006, I 7(5):527-533. 
4l. Pearson AM: Scavenger receptors in innate immunity. Current opinion in immunology 1996, 8(1):20-28.

42. Acton SL, Scherer PE, Lodish HF, Krieger M: Expression cloning of SR-BI, a CD36-related class B scavenger receptor. The Journal of biological chemistry 1994, 269(33):21003-21009.

43. Dinguirard N, Yoshino TP: Potential role of a CD36-like class B scavenger receptor in the binding of modified low-density lipoprotein (acLDL) to the tegumental surface of Schistosoma mansoni sporocysts. Mol Biochem Parasitol 2006 146(2):219-230.

44. Narazaki M, Segarra M, Tosato G: Sulfated polysaccharides identified as inducers of neuropilin-I internalization and functional inhibition of VEGF 165 and semaphorin3A. Blood 2008, I I I(8):4| 26-4I 36.

45. Kwon $\mathrm{KH}$, Ohigashi $\mathrm{H}$, Murakami A: Dextran sulfate sodium enhances interleukin-I beta release via activation of $p 38$ MAPK and ERKI/2 pathways in murine peritoneal macrophages. Life Sci 2007, 8 I(5):362-37I.

46. Abraham R, Singh N, Mukhopadhyay A, Basu SK, Bal V, Rath S: Modulation of immunogenicity and antigenicity of proteins by maleylation to target scavenger receptors on macrophages. J Immunol I995, I 54(I): I-8.

Publish with Bio Med Central and every scientist can read your work free of charge

"BioMed Central will be the most significant development for disseminating the results of biomedical research in our lifetime. "

Sir Paul Nurse, Cancer Research UK

Your research papers will be:

- available free of charge to the entire biomedical community

- peer reviewed and published immediately upon acceptance

- cited in PubMed and archived on PubMed Central

- yours - you keep the copyright

Submit your manuscript here:

http://www.biomedcentral.com/info/publishing_adv.asp
BioMedcentral 